\title{
Studies on the Effect of N, P, K Levels and Plant Densities on Growth, Yield and Quality of Pointed Gourd (Trichosanthes dioica Roxb.)
}

\author{
M. Siva ${ }^{1 *}$, T.S.K.K. Kiran Patro ${ }^{2}$, D. Dayeswari ${ }^{3}$, D.V. Swami ${ }^{4}$, \\ N. Emmanuel ${ }^{5}$ and M. Laksminarayana Reddy ${ }^{6}$ \\ ${ }^{1,2}$ Department of Vegetable Science, ${ }^{3}$ Department of Fruit Science, ${ }^{4}$ Department of Spices and \\ Plantation, ${ }^{5}$ Department of Entomology ${ }^{6}$ Dean of Horticulture, College of Horticulture, \\ Dr.Y.S.R Horticultural University, Venkataramannagudem, West Godavari, India
}

*Corresponding author

\section{Keywords}

NPK levels, Plant density, Pointed gourd, Growth, Yield and quality

\section{Article Info}

\section{Accepted:}

12 November 2018 Available Online:

10 December 2018

\section{A B S T R A C T}

The present study pertains to the effect of N,P,K levels, plant densities and its interaction on growth, yield and quality of pointed gourd (Trichosanthes Dioica Roxb.) was undertaken at College of Horticulture, Dr. Y.S.R Horticultural University, Venkataramannagudem, West Godavari District of Andhra Pradesh during kharif 20152016. An experiment was carried out with 12 different treatment combinations in factorial randomized block design (FRBD) replicated thrice which are $\left(\mathrm{T}_{1}\right)-\mathrm{F}_{1} \mathrm{~S}_{1}: 125: 50: 50 \mathrm{NPK}$ $\mathrm{kg} \mathrm{ha}^{-1}+1 \mathrm{mx} 1 \mathrm{~m} ;\left(\mathrm{T}_{2}\right)-\mathrm{F}_{1} \mathrm{~S}_{2}: 125: 50: 50 \mathrm{NPK} \mathrm{kg} \mathrm{ha}{ }^{-1}+1.5 \mathrm{mx} 1.5 \mathrm{~m} ;\left(\mathrm{T}_{3}\right)-\mathrm{F}_{1} \mathrm{~S}_{3}: 125: 50: 50$ NPK $\mathrm{kg} \mathrm{ha} \mathrm{a}^{-1}+1.5 \mathrm{mx} 1 \mathrm{~m} ;\left(\mathrm{T}_{4}\right)-\mathrm{F}_{2} \mathrm{~S}_{1}: 150: 60: 60 \mathrm{NPK} \mathrm{kg} \mathrm{ha}^{-1}+1 \mathrm{mx} 1 \mathrm{~m} ;\left(\mathrm{T}_{5}\right)-\mathrm{F}_{2} \mathrm{~S}_{2}$ : 150:60:60NPK kg ha ${ }^{-1}+1.5 \mathrm{mx} 1.5 \mathrm{~m} ;\left(\mathrm{T}_{6}\right) \mathrm{F}_{2} \mathrm{~S}_{3}: 150: 60: 60 \mathrm{NPK} \mathrm{kg} \mathrm{ha}{ }^{-1}+1.5 \mathrm{mx} 1 \mathrm{~m} ;\left(\mathrm{T}_{7}\right)-\mathrm{F}_{3}$ $\mathrm{S}_{1}$ : 175:70:70 NPK kg ha ${ }^{-1}+1 \mathrm{mx} 1 \mathrm{~m} ;\left(\mathrm{T}_{8}\right)-\mathrm{F}_{3} \mathrm{~S}_{2}: 175: 70: 70 \mathrm{NPK} \mathrm{kg} \mathrm{ha}{ }^{-1}+1.5 \mathrm{mx} 1.5 \mathrm{~m} ;\left(\mathrm{T}_{9}\right)-$ $\mathrm{F}_{3} \mathrm{~S}_{3}:$ 175:70:70 NPK kg ha ${ }^{-1}+1.5 \mathrm{mx} 1 \mathrm{~m} ;\left(\mathrm{T}_{10}\right)-\mathrm{F}_{4} \mathrm{~S}_{1}$ : Control $+1 \mathrm{mx} 1 \mathrm{~m} ;\left(\mathrm{T}_{11}\right)-\mathrm{F}_{4} \mathrm{~S}_{2}$ : Control+1.5mx1.5m; $\left(\mathrm{T}_{12}\right)-\mathrm{F}_{4} \mathrm{~S}_{3}$ : Control $+1.5 \mathrm{mx} 1 \mathrm{~m}$. Among the treatment combinations of N,P,K levels and plant densities, the treatment combination $\left(\mathrm{T}_{6}\right) \mathrm{F}_{2} \mathrm{~S}_{3}: 150: 60: 60 \mathrm{NPK}$ $\mathrm{kg} / \mathrm{ha}+1.5 \mathrm{~m} \times 1 \mathrm{~m}$ recorded maximum values for growth, yield and quality parameters viz., number of nodes per vine, number of primary branches per vine, number of fruits per vine, fruit length, fruit diameter, yield per vine, yield per plot, total yield, number of seeds per fruit, fruit retention percentage, ascorbic acid content, protein content and total soluble solids and the minimum values were recorded for the parameters node at which first male flower appeared, node at which first female flower appeared, days taken to first harvest and days taken from fruit set to marketable maturity. However, the application of $\left(\mathrm{T}_{8}\right)$ $\mathrm{S}_{2} \mathrm{~F}_{3}: 175: 70: 70 \mathrm{NPK} \mathrm{Kg} \mathrm{ha}^{-1}+1.5 \mathrm{~m} \times 1.5 \mathrm{~m}$ recorded maximum main vine length and internodal length whereas $\left(\mathrm{T}_{3}\right)-\mathrm{F}_{1} \mathrm{~S}_{3}: 125: 50: 50 \mathrm{NPK} \mathrm{Kg} \mathrm{Ka}^{-1}+1.5 \mathrm{~m} \times 1 \mathrm{~m}$ recorded minimum days taken for opening of first male flower and days taken for opening of first female flower. The application of $\left(\mathrm{T}_{5}\right)-\mathrm{F}_{2} \mathrm{~S}_{2}: 150: 60: 60 \mathrm{NPK} \mathrm{kg} / \mathrm{ha}+1.5 \mathrm{~m} \times 1.5 \mathrm{~m}$ recorded maximum weight of edible fruit, 100 seed weight, reducing sugars and total sugars. 


\section{Introduction}

Pointed gourd (Trichosanthes dioica Roxb.) is the king of gourds and belongs to the family Cucurbitaceae. It is popularly known as parwal, palwal, palmal, parmal, panal, patol and potala (Mondal et al., 2014), which is becoming more popular now a days. It is a perennial and dioecious vegetable that grows as vine with a pencil thickness stem (Hazra et al., 2011). Roots are tuberous with long tap root system. Leaves are dark green, simple cordate, ovate and oblong. Flowers are tubular, white and fruits are oblong and smooth. Propagation of pointed gourd from seed is not desirable due to poor seed germination as well as dioecism which results in around 50\% unproductive male plants. Traditionally pointed gourd is multiplied through stem cuttings and root suckers (Pandey and Ram, 2000). It has been observed that growers cultivate local cultivars and follow poor agro-techniques leading to low fruit yield. Lack of knowledge about the package of practices particularly on planting density and proper nutrient management are the prime reasons for lower yields.

Of late, agro techniques like nutrition and spacing play an important role in commercial production. Spacing is an important factor that will influence the plant population and affect the nutrient uptake of plants by creating competition between plants for nutrients, water and availability of light to the plants for synthesizing the food. By manipulation of inter and intra row spacing, several workers reported higher yields in other crops under field conditions (Singh et al., 2007), optimum nitrogen, phosphorus and potassium should be supplied to overcome the bottlenecks of production (Das et al., 1987). Several workers reported higher yields with the application nutrients in other cucurbitaceous crops (Misra et al., 1994). The need of the hour is to improve its production and quality of parwal crop through proper nutrient management.
Nitrogen fertilization favours the development of the aerial parts over roots and consequently the promotion of flowering and fruiting of many crops. Pointed gourd has huge vegetative growth which needs high amount of nitrogen (Hazra et al., 2011).

Phosphorus plays an important role in energy transformation and metabolic process of plant and stimulates early root formation and growth, gives a rapid and vigorous growth to plants. Phosphorous is needed in the genetic coding material which controls cell division. Potassium is an important element in plant metabolism, promoting carbohydrate translocation from tops to roots. It plays a major role in the production of fruits. Hence, it is necessary for enhancing the fruit yield and yield attributes. However, information on spacing, nitrogen, phosphorus and potassium requirements of pointed gourd is scarce under Indian conditions. So far, no work has been done on effect of $\mathrm{N}, \mathrm{P}, \mathrm{K}$ levels, plant densities and their interaction on growth, yield and quality parameters of pointed gourd. Hence, the present study was framed out to find better $\mathrm{N}, \mathrm{P}, \mathrm{K}$ management practices, plant densities for higher growth, yield and quality of pointed gourd. Hence, there is a need to standardize the optimum level of nitrogen, phosphorus and potassium for getting higher yields.

\section{Materials and Methods}

The experiment was conducted at College of Horticulture, Dr. Y. S.R. Horticultural University, Venkataramannagudem, West Godavari District during 2015-2016.

\section{Soil characteristics}

The soil used for experiment is red sandy loam soil, has good drainage and moderate water holding capacity. Soil samples were collected before transplanting the plants from five randomly selected locations at a depth of 0-30 
$\mathrm{cm}$ from the experimental plot and composite sample was analysed for its physico- chemical properties and presented in Table 1.

\section{Treatment details}

The details of the treatments were used are given in Table 2.

\section{Treatments}

N, P and K levels $\quad-\quad F_{1}: 125: 50: 50$ NPK $\mathrm{kg} \mathrm{ha}^{-1}$

$\mathrm{F}_{2}: 150: 60: 60 \mathrm{NPK} \mathrm{kg} \mathrm{ha}^{-1}$

$\mathrm{F}_{3}: 175: 70: 70 \mathrm{NPK} \mathrm{kg} \mathrm{ha}^{-1}$

$\mathrm{F}_{4}$ : Control

Plant densities $-\mathrm{S}_{1}: \quad \mathrm{S}_{1}-1 \mathrm{mx} 1 \mathrm{~m} \quad(10000$ Plants/ha)

$\begin{array}{llll} & \mathrm{S}_{2}: & 1.5 \mathrm{mx} 1.5 \mathrm{~m} & (4444 \\ \text { Plants/ha }) & \mathrm{S}_{3}: & 1.5 \mathrm{mx} 1 \mathrm{~m}\end{array}$

Plant/ha)

\section{Land preparation}

The land was brought to fine tilth by ploughing and harrowing. The experimental area was divided into plots of $6.0 \mathrm{~m} \mathrm{x} 2.0 \mathrm{~m}$ size. Irrigation channels of $1.0 \mathrm{~m}$ wide were provided for each row of plots. $30 \mathrm{~cm}^{3}$ pits were dug at a spacing of $1.0 \mathrm{~m} \times 1.0 \mathrm{~m}, 1.5 \mathrm{~m}$ $\mathrm{x} 1.5$ and $1.0 \mathrm{~m} \times 1.5 \mathrm{~m}$ in each plot. Well decomposed farmyard manure @ 10 kg per pit was incorporated by mixing with the soil uniformly as basal application and filled up to 3- $5 \mathrm{~cm}$ above the ground level.

\section{Planting}

Rooted vine cuttings of $15-20 \mathrm{~cm}$ length, pencil thickness and 2-3 months old plants were planted in recommended spacing of $1.0 \mathrm{mx} 1.0 \mathrm{~m}, 1.5 \mathrm{mx} 1.5 \mathrm{~m}$ and $1.5 \mathrm{mx} 1.0 \mathrm{~m}$. A space of 30 centimetres was uniformly left from the borders of the plot. Single rooted cutting was planted per pit.

\section{Manures and Fertilizers}

The recommended dosage of $\mathrm{N}, \mathrm{P}$ and $\mathrm{K}$ at 125: 50: $50 \mathrm{kgha}^{-1}$, 150: 60: $60 \mathrm{kgha}^{-1}$ and 175: $70: 70 \mathrm{kgha}^{-1}$ was applied in the form of urea, single super phosphate and muriate of potash respectively.

\section{Result and Discussion}

\section{Effect of $N, P, K$ levels and plant densities on vegetative parameters of pointed gourd}

\section{Main vine length (m)}

Main vine length differed significantly due to $\mathrm{N}, \mathrm{P}, \mathrm{K}$ level combinations. Significantly maximum main vine length $(10.0 \mathrm{~m})$ was observed with $F_{3}$ and it was followed by $F_{2}$ $(7.80 \mathrm{~m})$. The minimum main vine length $(5.62 \mathrm{~m})$ was recorded with $\mathrm{F}_{4}$ control (Table $3)$. Nitrogen is a very important component of protoplasm and its favourable effect on chlorophyll content of leaves might have increased synthesis of carbohydrates, amino acids etc., from which the phytohormones such as auxins, gibberellins, cytokinins and ethylene have been synthesized resulting increased plant height (Maynard and David, 1987). Anjanappa et al., (2012) in cucumber, Kanwar et al., (2013) in sweet pepper, Oloyede et al., (2013) in pumpkin, Arshad et al., (2014) in cucumber, Leghari et al., (2014) in bottle gourd, Das et al., (2015) in bottle gourd, Sureshkumar (2015) in bitter gourd and Umekwe et al., (2015) in cucumber were also reported increased plant height with increase in fertilizer levels.

The effect of plant density on main vine length was found to be significant. Significantly maximum main vine length $(8.58 \mathrm{~m})$ was recorded with low plant density $\left(\mathrm{S}_{2}-1.5 \times 1.5\right.$ $\mathrm{m})$, followed by main vine length $(7.45 \mathrm{~m})$ with medium plant density $\left(\mathrm{S}_{3}-1.5 \times 1 \mathrm{~m}\right)$. However, the minimum main vine length $(6.91 \mathrm{~m})$ was recorded with high plant density 
$\left(\mathrm{S}_{1}-1 \times 1 \mathrm{~m}\right)$. This could be due to availability of more space, nutrients, water and less competition from the adjacent plants in wider planting when compared to closer spaced plants. Dash and Tripathy (2001) in pointed gourd, Choudhari and More (2002) in cucumber, Singh et al., (2012) in tomato and Aniekwe and Anike (2015). The interaction effect due to nutrient combinations and plant densities on main vine length was found to be significant. The treatment combination $\left(\mathrm{T}_{8}\right)$ $\mathrm{F}_{3} \mathrm{~S}_{2}$ produced maximum main vine length $(11.93 \mathrm{~m})$ which was followed by $\left(\mathrm{T}_{9}\right)-\mathrm{F}_{3} \mathrm{~S}_{3}$ $(9.55 \mathrm{~m})$. However the treatment combination $\left(\mathrm{T}_{10}\right)-\mathrm{F}_{4} \mathrm{~S}_{1}$ recorded the minimum vine length $(5.26 \mathrm{~m})$. These results are in conformity with the findings of Aidy and Moustafa (1978) in cucumber, Jan et al., (2000) in bottle gourd and Choudhari and More (2002) in cucumber.

\section{Number of nodes per vine}

Number of nodes per vine was varied significantly with fertilizer levels and plant densities. It was evident from the data that higher number of nodes per vine (186.08) was recorded with medium plant density $S_{2}: 1.5 \times 1$ $\mathrm{m}$ followed by (178.12) the lowest plant density with $S_{1}: 1 \times 1 \mathrm{~m}$ spacing. However the minimum number of nodes per vine (170.83) was recorded with wider plant density $\mathrm{S}_{2}: 1.5 \mathrm{x}$ $1.5 \mathrm{~m}$ (Table 4). These results were in conformity with the findings of Karataev and Salnikova (1982) in parthenocarpic cucumber and Ekmw and Nwokwu (2012) in bhendi. The interaction effect of nutrient combinations and plant densities were non significant in number of nodes per vine.

\section{Effect of N, P, K levels and plant densities on floral parameters of pointed gourd}

\section{Days taken for opening of first male flower}

Interaction effect due to fertilizer combinations and plant densities on number of days taken for opening of first male flower was found to be significant. The treatment combination $\left(T_{3}\right)-F_{1} S_{3}$ produced minimum number of days taken for opening of first male flower (40.66 days) which was followed by $\left(\mathrm{T}_{2}\right)-\mathrm{F}_{1} \mathrm{~S}_{2}$ (41.00 days). However the treatment combination $\left(\mathrm{T}_{10}\right)-\mathrm{F}_{4} \mathrm{~S}_{1}$ recorded the maximum number of days taken for opening of first male flower (59.00 days) (Fig. 1a). These results were in conformity with the findings of Yadav et al., (1989) in pointed gourd, Vishwakarma et al., (2007) in spine gourd and Prasad et al., (2009) in bitter gourd.

\section{Days taken for opening of first female flower}

Interaction effect due to fertilizer combinations and plant densities on number of days taken for opening of first female flower was found to be significant. The treatment combination $F_{1} S_{3}$ produced minimum number of days taken for opening of first female flower (58 days) which was followed by $\left(\mathrm{T}_{2}\right)$ $\mathrm{F}_{1} \mathrm{~S}_{2}$ (60.66 days). However the treatment combination $\left(\mathrm{T}_{10}\right)-\mathrm{F}_{4} \mathrm{~S}_{1}$ and $\left(\mathrm{T}_{11}\right)-\mathrm{F}_{4} \mathrm{~S}_{2}$ recorded the maximum number of days (Fig. 1b) taken for opening of first male flower $(72$ days). Less number of days taken in the appearance of first female flower with lower doses of nitrogen might be due to poor early vegetative growth and hastening the initiation of reproduction phase. These results were in conformity with the findings of Yadav et al., (1989) in pointed gourd, Vishwakarma et al., (2007) in spine gourd, Prasad et al., (2009) in bitter gourd.

Effect of N, P, K levels and plant densities on yield parameters of pointed gourd

\section{Days taken to first harvest}

The interaction due to combined effect of $\mathrm{N}$, $\mathrm{P}, \mathrm{K}$, levels and plant densities and their interactions was significant. The days taken for first harvest were found to be significant. The treatment combination $\left(\mathrm{T}_{6}\right)-\mathrm{F}_{2} \mathrm{~S}_{3}$ produced 
minimum days taken to first harvest (63.46) which was followed by $\left(\mathrm{T}_{5}\right)-\mathrm{F}_{2} \mathrm{~S}_{2}$ (83.11). However the treatment combination $\left(\mathrm{T}_{11}\right)-\mathrm{F}_{4} \mathrm{~S}_{2}$ recorded the maximum days taken to first harvest (119.35) (Table 5). These results were in conformity with the findings of Yadav et al., (1989); Das et al., (2004) in pointed gourd, Prabhu et al., (2006) in cucumber, Vishwakarma et al., (2007) in spine gourd, Kanwar et al., (2013) in sweet pepper, Kumar et al., (2012) in bottle gourd and Wazed et al., (2013) in snake gourd.

\section{Number of fruits per vine}

Effect of N, P, K levels, plant densities and their interaction effect on number of fruits per vine varied significantly. Among the interaction effect, the higher number of fruits per vine (225.67) was recorded with $\left(\mathrm{T}_{6}\right)-\mathrm{F}_{2} \mathrm{~S}_{3}$ followed by $\left(\mathrm{T}_{5}\right)-\mathrm{F}_{2} \mathrm{~S}_{2}$ (198.63), the lower number of fruits per vine (85.00) was recorded (Fig. 2) with $\left(\mathrm{T}_{10}\right)-\mathrm{F}_{4} \mathrm{~S}_{1}$. These results were in conformity with the findings of Jan et al., (2000) in bottle gourd, Choudhari and More (2002) in cucumber and Patro and Mallareddy (2009) in kakrol.

\section{Yield per vine (kg)}

Effect of N, P, K levels, plant density and their interactions differed significantly for yield per vine. The higher yield per vine $\left(9.5 \mathrm{~kg}\right.$ vine $\left.{ }^{-1}\right)$ was recorded with $\left(\mathrm{T}_{6}\right)-\mathrm{F}_{2} \mathrm{~S}_{3}$ which was followed by $\left(\mathrm{T}_{5}\right)-\mathrm{F}_{2} \mathrm{~S}_{2}\left(8.62 \mathrm{~kg} \quad\right.$ vine $\left.^{-1}\right)$. However the lowest yield per vine $(2.21 \mathrm{~kg}$ vine $^{-1}$ ) was recorded $\left(\mathrm{T}_{10}\right)-\mathrm{F}_{4} \mathrm{~S}_{1}$ (Table 6). These results indicated that the efficiency of nitrogen increased considerably by a simultaneous application of phosphorus and potassium. Improvement of vegetative growth and fruiting could be due to combined application of nitrogen, phosphorus and potassium. The fruit yield per plant in terms of number and total weight of fruits was more in medium spaced plants compared to narrow spaced plants could be due to more number of branches, leaf area, availability of nutrients, light, water and less competition from adjacent plants. These results were in conformity with the findings of Karataev and Salnikova (1982) in parthenocarpic cucumber, Yadav et al., (1989) in pointed gourd, Choudhari and More (2002) in cucumber, Jan et al., (2000) in bottle gourd, Shivashankaramurthy et al., (2007) in gherkins and Patro and Mallareddy (2009) in kakrol.

\section{Yield per plot (kg)}

Yield per plot effect on $\mathrm{N}, \mathrm{P}, \mathrm{K}$ levels fertilizers and plant densities differed significantly for yield per plot. The maximum yield per plot $\left(67.90 \mathrm{~kg} \mathrm{plot}^{-1}\right)$ was attained with the treatment combination of $\left(\mathrm{T}_{6}\right)-\mathrm{F}_{2} \mathrm{~S}_{3}$ which was followed by $\left(\mathrm{T}_{9}\right)-\mathrm{F}_{3} \mathrm{~S}_{3}(61.70 \mathrm{~kg}$ plot $\left.^{-1}\right)$, whereas $\left(\mathrm{T}_{10}\right)-\mathrm{F}_{4} \mathrm{~S}_{1}$ gave the minimum plot yield (13.50 kg plot ${ }^{-1}$ ) compared to the all other treatment combinations (Table 7) and this might be due to nitrogen which results in the increase in the number of leaves, number of branches resulting in the higher chlorophyll and higher photosynthetic activity which helps in the production of carbohydrates which were trans located to the fruits with the help of potassium. Hence the positive response of fruit yield to increased rates of $\mathrm{N}$ and $\mathrm{K}$ could be due to high starch synthesis and translocation activities stimulated by $\mathrm{N}$ and $\mathrm{K}$ application. These results were in conformity with the findings of Shivashankaramurthy et al., (2007) in gherkins, Karataev and Salnikova (1982) in parthenocarpic cucumber and Aidy and Moustafa (1978) in cucumber.

\section{Total yield ( $\left.\mathrm{ha}^{-\mathbf{1}}\right)$}

Increase in NPK level combinations increased the yield significantly in pointed gourd. The higher total yield $\left(41.98 \mathrm{t} \mathrm{ha}^{-1}\right)$ was recorded with the treatment $F_{2}$ followed by the treatment $\mathrm{F}_{3}\left(40.01 \mathrm{t} \mathrm{ha}^{-1}\right)$, whereas lower total yield (12.14 $\left.\mathrm{t} \mathrm{ha}^{-1}\right)$ was reported with the 
treatment $\mathrm{F}_{4}$ control. These results were in conformity with the findings of Umamaheswarappa et al., (2002) in bottle gourd, Das et al., (2004) in pointed gourd, Anjanappa et al., (2012) in cucumber, Rani et al., (2012) in pointed gourd, Mia et al., (2014) in bitter gourd and Arshad et al., (2014) in cucumber. The total yield of pointed gourd was significantly influenced by difference in the plant densities. Significantly higher yield $\left(29.60 \mathrm{t} \mathrm{ha}^{-1}\right)$ was recorded with the plant density $\mathrm{S}_{3}$ followed by the plant density $\mathrm{S}_{2}$ which recorded yield of $26.53 \mathrm{tha}^{-1}$, while minimum yield $\left(24.61 \mathrm{t} \mathrm{ha}^{-1}\right)$ was recorded with plant density, $S_{1}(1 \times 1 \mathrm{~m})$. At medium plant density the performance of individual plants was improved with respect to yield components. These results were in conformity with the findings of Singh et al., (2007) in pointed gourd, Oga and Umekwe (2016) in water melon. The interaction effect due to NPK levels combinations and plant densities on total yield was found to be significant. Significantly maximum total yield (47.66 $\mathrm{tha}^{-}$ $\left.{ }^{1}\right)$ was attained with the treatment combination of $\left(T_{6}\right)-F_{2} S_{3}$ which was followed by $\left(T_{9}\right)-F_{3} S_{3}$ (46.33 $\mathrm{t} \mathrm{ha}^{-1}$ ), whereas $\left(\mathrm{T}_{11}\right)-\mathrm{F}_{4} \mathrm{~S}_{2}$ gave the minimum total yield $\left(12.00 \mathrm{t} \mathrm{ha}^{-1}\right)$ compared to the all other treatment combinations (Table $8)$. These results were in conformity with the findings of Aidy and Moustafa (1978) in cucumber, Jan et al., (2000) in bottle gourd and Choudhari and More (2002) in cucumber.

\section{Effect of N, P, K levels and plant densities on quality of pointed gourd}

\section{Weight of the edible fruit (g)}

The interaction pertaining to $\mathrm{N}, \mathrm{P}, \mathrm{K}$ levels and plant densities recorded higher fruit weight with $\left(\mathrm{T}_{5}\right)-\mathrm{F}_{2} \mathrm{~S}_{2}(44.9 \mathrm{~g})$ which was followed by $\left(\mathrm{T}_{6}\right)-\mathrm{F}_{2} \mathrm{~S}_{3}(39.9 \mathrm{~g})$. The lower weight of edible fruit $(22.13 \mathrm{~g})$ was recorded with $\left(\mathrm{T}_{10}\right)-\mathrm{F}_{4} \mathrm{~S}_{1}$, which might be due to availability of balanced amount of nutrients and higher rate of assimilation and ultimately more production of carbohydrates and their translocation to the storage organs like fruits. These results indicated that the efficiency of nitrogen increased considerably by a simultaneous application of phosphorus and potassium (Fig. 3a). Improvement of vegetative growth and fruiting could be due to combined application of nitrogen, phosphorus and potassium. Similar results were in conformity with the findings of Umamaheswarappa et al., (2002) in bottlegourd, Choudhary et al., (2007) in capsicum, Jan et al., (2000) in bottle gourd, Choudhari and More (2002) in cucumber and Patro and Mallareddy (2009) in kakrol.

\section{Length of the edible fruit $(\mathrm{cm})$}

The effect of N,P,K fertilizer levels and plant densities recorded higher length of edible fruits with $\left(\mathrm{T}_{6}\right)-\mathrm{F}_{2} \mathrm{~S}_{3}(14.3 \mathrm{~cm})$ which was followed by $\left(\mathrm{T}_{8}\right)-\mathrm{F}_{3} \mathrm{~S}_{2}(11.61 \mathrm{~cm})$. The lower length of edible fruit $(7.19 \mathrm{~cm})$ was recorded with $\left(\mathrm{T}_{10}\right)-\mathrm{F}_{4} \mathrm{~S}_{1}$ (Fig. 3b). These results were in conformity with the findings of Yadav et al., (1989) in pointed gourd.

\section{Fruit diameter (cm)}

The interaction effect of $\mathrm{N}, \mathrm{P}, \mathrm{K}$ fertilizer levels and plant density recorded higher for fruit diameter with $\left(\mathrm{T}_{6}\right)-\mathrm{F}_{2} \mathrm{~S}_{3}(6.56 \mathrm{~cm})$ which was followed by $\left(\mathrm{T}_{5}\right)-\mathrm{F}_{2} \mathrm{~S}_{2}(5.85 \mathrm{~cm})$. The lower fruit diameter $(3.07 \mathrm{~cm})$ was recorded with $\left(\mathrm{T}_{11}\right)-\mathrm{F}_{4} \mathrm{~S}_{2}$ (Fig. 3c). These results were in conformity with the findings of Choudhari and More (2002) in cucumber and Shivashankara murthy et al., (2007) in gherkins.

\section{Effect of N, P, K levels and plant densities on biochemical parameters of pointed gourd}

\section{Ascorbic acid content (mg/100 g)}

The combined effect of $\mathrm{N}, \mathrm{P}, \mathrm{K}$ fertilizer levels and plant density and its interaction was 
significant in improving the ascorbic acid content. Significantly highest superior ascorbic acid content $(33.2 \mathrm{mg})$ was attained with the treatment combination of $\left(\mathrm{T}_{6}\right)-\mathrm{F}_{2} \mathrm{~S}_{3}$ which was followed by $\left(\mathrm{T}_{5}\right)-\mathrm{F}_{2} \mathrm{~S}_{2}(29.66 \mathrm{mg})$, whereas $\left(\mathrm{T}_{10}\right)-\mathrm{F}_{4} \mathrm{~S}_{1}$ gave the lowest ascorbic acid content $(22.5 \mathrm{mg})$ compared to the all other treatment combinations (Fig. 4a). The improvement of ascorbic acid content at medium fertilizer levels and plant densities might have led to more nitrogenous compounds in plant tissues and ultimately resulted in their efficient metabolism. These results were in conformity with the findings of Shivashankaramurthy et al., (2007) in gherkins.

Table.1 Physical and chemical properties of soil experimental site

\begin{tabular}{|c|c|c|}
\hline Properties & Value & Method of analysis \\
\hline \multicolumn{3}{|l|}{ A. Physical composition } \\
\hline Sand $(\%)$ & $70 \%$ & $\begin{array}{l}\text { International pipette } \quad \text { method } \\
\text { (Piper,1966) }\end{array}$ \\
\hline Silt (\%) & $20 \%$ & - \\
\hline Clay (\%) & $10 \%$ & - \\
\hline Textural class & Red sandy loam & - \\
\hline \multicolumn{3}{|l|}{ B. Chemical composition } \\
\hline Soil pH & 6.98 & $\begin{array}{l}\text { Digital pH meter (DI-707) } \\
\text { (Jackson,1973) }\end{array}$ \\
\hline $\begin{array}{l}\text { Electrical conductivity }\left(\mathrm{ds} \mathrm{m}^{-}\right. \\
\left.{ }_{1}^{-}\right)\end{array}$ & 0.26 & Conductivity Bridge (Jackson,1973) \\
\hline Available Nitrogen $\left(\mathrm{kg} \mathrm{ha}^{-1}\right)$ & 140 & $\begin{array}{l}\text { Alkaline permanganate method } \\
\text { (Subbaiah and Asija,1956) }\end{array}$ \\
\hline $\begin{array}{l}\text { Available Phosphorus(kg ha- } \\
{ }_{1} \text { ) }\end{array}$ & 41 & Olsen’s method (Olsen,1954) \\
\hline Available Potassium(kg ha $\left.{ }^{-1}\right)$ & 170 & Flame photometer method (Muhr,1965) \\
\hline
\end{tabular}

Table.2 Combination of N,P,K levels and Plant density treatments

\begin{tabular}{|c|c|}
\hline Treatment Notation & Combination of $\mathrm{N}, \mathrm{P}, \mathrm{K}$ levels and Plant density treatments \\
\hline $\mathrm{T}_{1}$ & $\mathrm{~F}_{1} \mathrm{~S}_{1}: 125: 50: 50 \mathrm{NPK} \mathrm{kg} \mathrm{ha}{ }^{-1}+1 \mathrm{mx} 1 \mathrm{~m}$ \\
\hline $\mathrm{T}_{2}$ & $F_{1} S_{2}: 125: 50: 50 \mathrm{NPK} \mathrm{kg} \mathrm{ha}^{-1}+1.5 \mathrm{mx} 1.5 \mathrm{~m}$ \\
\hline $\mathrm{T}_{3}$ & $F_{1} S_{3}: 125: 50: 50 \mathrm{NPK} \mathrm{kg} \mathrm{ha}^{-1}+1.5 \mathrm{mx} 1 \mathrm{~m}$ \\
\hline $\mathrm{T}_{4}$ & $\mathrm{~F}_{2} \mathrm{~S}_{1}: 150: 60: 60 \mathrm{NPK} \mathrm{kg} \mathrm{ha}{ }^{-1}+1 \mathrm{mx} 1 \mathrm{~m}$ \\
\hline $\mathrm{T}_{5}$ & $\mathrm{~F}_{2} \mathrm{~S}_{2}: 150: 60: 60 \mathrm{NPK} \mathrm{kg} \mathrm{ha}{ }^{-1}+1.5 \mathrm{mx} 1.5 \mathrm{~m}$ \\
\hline $\mathrm{T}_{6}$ & $\mathrm{~F}_{2} \mathrm{~S}_{3}: 150: 60: 60 \mathrm{NPK} \mathrm{kg} \mathrm{ha}{ }^{-1}+1.5 \mathrm{mx} 1 \mathrm{~m}$ \\
\hline $\mathrm{T}_{7}$ & $\mathrm{~F}_{3} \mathrm{~S}_{1}: 175: 70: 70 \mathrm{NPK} \mathrm{kg} \mathrm{ha}^{-1}+1 \mathrm{mx} 1 \mathrm{~m}$ \\
\hline $\mathrm{T}_{8}$ & $\mathrm{~F}_{3} \mathrm{~S}_{2}: 175: 70: 70 \mathrm{NPK} \mathrm{kg} \mathrm{ha}{ }^{-1}+1.5 \mathrm{mx} 1.5 \mathrm{~m}$ \\
\hline $\mathrm{T}_{9}$ & $\mathrm{~F}_{3} \mathrm{~S}_{3}: 175: 70: 70 \mathrm{NPK} \mathrm{kg} \mathrm{ha}{ }^{-1}+1.5 \mathrm{mx} 1 \mathrm{~m}$ \\
\hline $\mathrm{T}_{10}$ & $\mathrm{~F}_{4} \mathrm{~S}_{1}$ : Control+1mx $1 \mathrm{~m}$ \\
\hline $\mathrm{T}_{11}$ & $\mathrm{~F}_{4} \mathrm{~S}_{2}$ : Control+1.5mx $1.5 \mathrm{~m}$ \\
\hline $\mathrm{T}_{12}$ & $\mathrm{~F}_{4} \mathrm{~S}_{3}:$ Control+1.5mx $1 \mathrm{~m}$ \\
\hline
\end{tabular}


Table.3 Effect of N, P, K levels and plant densities on main vine length (m) in pointed gourd (Trichosanthes dioica Roxb.)

\begin{tabular}{|l|l|l|l|l|}
\hline & $\mathrm{S}_{1}$ & $\mathrm{~S}_{2}$ & $\mathrm{~S}_{3}$ & Mean \\
\hline $\mathrm{F}_{1}$ & 6.64 & 7.91 & 6.95 & $\mathbf{7 . 1 6}$ \\
\hline $\mathrm{F}_{2}$ & 7.22 & 8.65 & 7.54 & $\mathbf{7 . 8 0}$ \\
\hline $\mathrm{F}_{3}$ & 8.53 & 11.93 & 9.55 & $\mathbf{1 0 . 0 0}$ \\
\hline $\mathrm{F}_{4}$ & 5.26 & 5.85 & 5.74 & $\mathbf{5 . 6 2}$ \\
\hline Mean & $\mathbf{6 . 9 1}$ & $\mathbf{8 . 5 8}$ & $\mathbf{7 . 4 5}$ & \\
\hline
\end{tabular}

\begin{tabular}{|c|c|c|c|}
\hline & F & S & F x S \\
\hline SEm & 0.21 & 0.18 & 0.37 \\
\hline SEd \pm & 0.30 & 0.26 & 0.52 \\
\hline CD at 5\% & 0.62 & 0.54 & 1.09 \\
\hline
\end{tabular}

Nutrient combinations

$\mathrm{F}_{1}: 125: 50: 50 \mathrm{NPK} \mathrm{Kg} / \mathrm{ha}$

$\mathrm{F}_{2}: 150: 60: 60 \mathrm{NPK} \mathrm{Kg} / \mathrm{ha}$

$\mathrm{F}_{3}: 175: 70: 70 \mathrm{NPK} \mathrm{Kg} / \mathrm{ha}$

$\mathrm{F}_{4}:$ Control
Plant densities

$$
\begin{aligned}
& \mathrm{S}_{1}: 1 \mathrm{~m} \times 1 \mathrm{~m} \\
& \mathrm{~S}_{2}: 1.5 \mathrm{~m} \times 1.5 \mathrm{~m} \\
& \mathrm{~S}_{3}: 1.5 \mathrm{~m} \times 1 \mathrm{~m}
\end{aligned}
$$

Table.4 Effect of N, P, K levels and plant densities on number of nodes per vine in pointed gourd (Trichosanthes dioica Roxb.)

\begin{tabular}{|l|l|l|l|l|}
\hline & $\mathrm{S}_{1}$ & $\mathrm{~S}_{2}$ & $\mathrm{~S}_{3}$ & Mean \\
\hline $\mathrm{F}_{1}$ & 174.50 & 160.66 & 178.00 & $\mathbf{1 7 3 . 0 5}$ \\
\hline $\mathrm{F}_{2}$ & 190.66 & 182.00. & 205.33 & $\mathbf{1 9 2 . 6 6}$ \\
\hline $\mathrm{F}_{3}$ & 189.00 & 177.66 & 198.00 & $\mathbf{1 8 8 . 2 2}$ \\
\hline $\mathrm{F}_{4}$ & 158.33 & 157.00 & 163.00 & $\mathbf{1 5 9 . 4 4}$ \\
\hline Mean & $\mathbf{1 7 8 . 1 2}$ & $\mathbf{1 7 0 . 8 3}$ & $\mathbf{1 8 6 . 0 8}$ & \\
\hline
\end{tabular}

\begin{tabular}{|c|c|c|c|}
\hline & F & S & F x S \\
\hline SEm & 2.60 & 2.25 & 4.51 \\
\hline SEd \pm & 3.68 & 3.19 & 6.38 \\
\hline CD at 5\% & 7.64 & 6.62 & N.S \\
\hline
\end{tabular}

Nutrient combinations

$\mathrm{F}_{1}: 125: 50: 50 \mathrm{NPK} \mathrm{Kg} / \mathrm{ha}$

$\mathrm{F}_{2}:$ 150:60:60 NPK Kg/ha

$\mathrm{F}_{3}: 175: 70: 70 \mathrm{NPK} \mathrm{Kg} / \mathrm{ha}$

$\mathrm{F}_{4}$ : Control

\section{Plant densities}

$\mathrm{S}_{1}: 1 \mathrm{~m} \times 1 \mathrm{~m}$

$\mathrm{S}_{2}: 1.5 \mathrm{mx} 1.5 \mathrm{~m}$

$\mathrm{S}_{3}: 1.5 \mathrm{~m} \times 1 \mathrm{~m}$ 
Table.5 Effect of N, P, K levels and plant densities on days taken to first harvest in pointed gourd (Trichosanthes dioica Roxb.)

\begin{tabular}{|l|l|l|l|l|}
\hline & $\mathrm{S}_{1}$ & $\mathrm{~S}_{2}$ & $\mathrm{~S}_{3}$ & Mean \\
\hline $\mathrm{F}_{1}$ & 107.4 & 97.66 & 85.36 & $\mathbf{9 6 . 8 1}$ \\
\hline $\mathrm{F}_{2}$ & 88.49 & 83.11 & 63.46 & $\mathbf{7 8 . 3 5}$ \\
\hline $\mathrm{F}_{3}$ & 98.98 & 93.03 & 83.76 & $\mathbf{9 1 . 9 2}$ \\
\hline $\mathrm{F}_{4}$ & 119.35 & 120.55 & 118.00 & $\mathbf{1 1 9 . 3 5}$ \\
\hline Mean & $\mathbf{1 0 3 . 5 9}$ & $\mathbf{9 8 . 5 9}$ & $\mathbf{8 7 . 6 5}$ & \\
\hline
\end{tabular}

\begin{tabular}{|c|c|c|c|}
\hline & F & S & F X S \\
\hline SEm & 1.80 & 1.56 & 3.13 \\
\hline SEd \pm & 2.55 & 2.21 & 4.43 \\
\hline CD at $5 \%$ & 5.30 & 4.59 & 9.19 \\
\hline
\end{tabular}

\section{Nutrient combinations}

$\mathrm{F}_{1}: 125: 50: 50 \mathrm{NPK} \mathrm{Kg} / \mathrm{ha}$

$\mathrm{F}_{2}: 150: 60: 60 \mathrm{NPK} \mathrm{Kg} / \mathrm{ha}$

$\mathrm{F}_{3}: 175: 70: 70 \mathrm{NPK} \mathrm{Kg} / \mathrm{ha}$

$\mathrm{F}_{4}$ : Control

$$
\begin{aligned}
& \text { Plant densities } \\
& \mathrm{S}_{1}: 1 \mathrm{~m} \times 1 \mathrm{~m} \\
& \mathrm{~S}_{2}: 1.5 \mathrm{~m} \times 1.5 \mathrm{~m} \\
& \mathrm{~S}_{3}: 1.5 \mathrm{~m} \times 1 \mathrm{~m}
\end{aligned}
$$

Table.6 Effect of N, P, K levels and plant densities on yield per vine (kg) in pointed gourd (Trichosanthes dioica Roxb.)

\begin{tabular}{|l|l|l|l|l|}
\hline & $\mathrm{S}_{1}$ & $\mathrm{~S}_{2}$ & $\mathrm{~S}_{3}$ & Mean \\
\hline $\mathrm{F}_{1}$ & 6.43 & 7.03 & 7.86 & $\mathbf{7 . 1 0}$ \\
\hline $\mathrm{F}_{2}$ & 7.93 & 8.62 & 9.5 & $\mathbf{8 . 6 8}$ \\
\hline $\mathrm{F}_{3}$ & 7.30 & 8.33 & 8.43 & $\mathbf{8 . 0 2}$ \\
\hline $\mathrm{F}_{4}$ & 2.21 & 2.41 & 2.61 & $\mathbf{2 . 4 3}$ \\
\hline Mean & $\mathbf{5 . 9 6}$ & $\mathbf{6 . 5 9}$ & $\mathbf{7 . 1 1}$ & \\
\hline
\end{tabular}

\begin{tabular}{|c|c|c|c|}
\hline & F & S & F x S \\
\hline SEm & 0.21 & 0.18 & 0.37 \\
\hline SEd \pm & 0.30 & 0.26 & 0.53 \\
\hline CD at $5 \%$ & 0.63 & 0.55 & 1.10 \\
\hline
\end{tabular}

\section{Nutrient combinations}

$\mathrm{F}_{1}: 125: 50: 50 \mathrm{NPK} \mathrm{Kg} / \mathrm{ha}$

$\mathrm{F}_{2}:$ 150:60:60 NPK Kg/ha

$\mathrm{F}_{3}: 175: 70: 70 \mathrm{NPK} \mathrm{Kg} / \mathrm{ha}$

$\mathrm{F}_{4}$ : Control

\section{Plant densities}

$\mathrm{S}: 1 \mathrm{~m} \times 1 \mathrm{~m}$

$\mathrm{S}_{2}: 1.5 \mathrm{mx} 1.5 \mathrm{~m}$

$\mathrm{S}_{3}: 1.5 \mathrm{~m} \times 1 \mathrm{~m}$ 
Table.7 Effect of N, P, K levels and plant densities on yield per plot (kg) in pointed gourd (Trichosanthes dioica Roxb.)

\begin{tabular}{|l|l|l|l|l|}
\hline & $\mathrm{S}_{1}$ & $\mathrm{~S}_{2}$ & $\mathrm{~S}_{3}$ & Mean \\
\hline $\mathrm{F}_{1}$ & 40.86 & 44.3 & 55.13 & $\mathbf{4 6 . 7 6}$ \\
\hline $\mathrm{F}_{2}$ & 49.43 & 52.40 & 67.90 & $\mathbf{5 6 . 5 7}$ \\
\hline $\mathrm{F}_{3}$ & 44.00 & 49.86 & 61.70 & $\mathbf{5 1 . 8 5}$ \\
\hline $\mathrm{F}_{4}$ & 13.50 & 13.60 & 13.90 & $\mathbf{1 3 . 6 6}$ \\
\hline Mean & $\mathbf{3 6 . 9 4}$ & $\mathbf{4 0 . 0 4}$ & $\mathbf{4 9 . 6 5}$ & \\
\hline
\end{tabular}

\begin{tabular}{|c|c|c|c|}
\hline & F & S & F x S \\
\hline SEm & 1.44 & 1.25 & 2.51 \\
\hline SEd \pm & 2.05 & 1.77 & 3.55 \\
\hline CD at $5 \%$ & 4.25 & 3.68 & 7.36 \\
\hline
\end{tabular}

\section{Nutrient combinations}

$\mathrm{F}_{1}:$ 125:50:50 NPK Kg/ha

$\mathrm{F}_{2}: 150: 60: 60 \mathrm{NPK} \mathrm{Kg} / \mathrm{ha}$

$\mathrm{F}_{3}: 175: 70: 70 \mathrm{NPK} \mathrm{Kg} / \mathrm{ha}$

$\mathrm{F}_{4}:$ Control

$$
\begin{aligned}
& \text { Plant densities } \\
& \mathrm{S}_{1}: 1 \mathrm{~m} \times 1 \mathrm{~m} \\
& \mathrm{~S}_{2}: 1.5 \mathrm{~m} \times 1.5 \mathrm{~m} \\
& \mathrm{~S}_{3}: 1.5 \mathrm{~m} \times 1 \mathrm{~m}
\end{aligned}
$$

Table.8 Effect of N, P, K levels and plant densities on total yield ( $\left.\mathrm{t} \mathrm{ha}^{-1}\right)$ in pointed gourd (Trichosanthes dioica Roxb.)

\begin{tabular}{|l|l|l|l|l|}
\hline & $\mathrm{S}_{1}$ & $\mathrm{~S}_{2}$ & $\mathrm{~S}_{3}$ & Mean \\
\hline $\mathrm{F}_{1}$ & 31.40 & 32.70 & 37.00 & $\mathbf{3 3 . 7 0}$ \\
\hline $\mathrm{F}_{2}$ & 37.56 & 40.73 & 47.66 & $\mathbf{4 1 . 9 8}$ \\
\hline $\mathrm{F}_{3}$ & 35.00 & 38.70 & 46.33 & $\mathbf{4 0 . 0 1}$ \\
\hline $\mathrm{F}_{4}$ & 12.15 & 12.00 & 12.29 & $\mathbf{1 2 . 1 4}$ \\
\hline Mean & $\mathbf{2 4 . 6 1}$ & $\mathbf{2 6 . 5 3}$ & $\mathbf{2 9 . 6 0}$ & \\
\hline
\end{tabular}

\begin{tabular}{|c|c|c|c|}
\hline & F & S & F x S \\
\hline SEm & 0.92 & 0.79 & 1.59 \\
\hline SEd \pm & 1.30 & 1.12 & 2.25 \\
\hline CD at $5 \%$ & 2.69 & 2.33 & 4.67 \\
\hline
\end{tabular}

Nutrient combinations

$\mathrm{F}_{1}: 125: 50: 50 \mathrm{NPK} \mathrm{Kg} / \mathrm{ha}$

$\mathrm{F}_{2}: 150: 60: 60 \mathrm{NPK} \mathrm{Kg} / \mathrm{ha}$

$\mathrm{F}_{3}: 175: 70: 70 \mathrm{NPK} \mathrm{Kg} / \mathrm{ha}$

$\mathrm{F}_{4}$ : Control

\section{Plant densities}

$\mathrm{S}_{1}: 1 \mathrm{~m} \times 1 \mathrm{~m}$

$\mathrm{S}_{2}: 1.5 \mathrm{mx} 1.5 \mathrm{~m}$

$\mathrm{S}: 1.5 \mathrm{~m} \times 1 \mathrm{~m}$ 
Table.9 Effect of N, P, K levels and plant densities on reducing sugars (\%) in pointed gourd (Trichosanthes dioica Roxb.)

\begin{tabular}{|l|l|l|l|l|}
\hline & $\mathrm{S}_{1}$ & $\mathrm{~S}_{2}$ & $\mathrm{~S}_{3}$ & Mean \\
\hline $\mathrm{F}_{1}$ & 1.67 & 1.82 & 1.78 & $\mathbf{1 . 7 5}$ \\
\hline $\mathrm{F}_{2}$ & 2.40 & 2.91 & 2.88 & $\mathbf{2 . 7 3}$ \\
\hline $\mathrm{F}_{3}$ & 2.13 & 2.40 & 2.21 & $\mathbf{2 . 2 4}$ \\
\hline $\mathrm{F}_{4}$ & 1.64 & 1.70 & 1.66 & $\mathbf{1 . 6 6}$ \\
\hline Mean & $\mathbf{1 . 9 6}$ & $\mathbf{2 . 2 0}$ & $\mathbf{2 . 1 3}$ & \\
\hline
\end{tabular}

\begin{tabular}{|c|c|c|c|}
\hline & F & S & F X S \\
\hline SEm & 0.02 & 0.02 & 0.04 \\
\hline SEd \pm & 0.03 & 0.03 & 0.06 \\
\hline CD at 5\% & 0.07 & 0.06 & 0.13 \\
\hline
\end{tabular}

Table.10 Effect of N, P, K levels and plant densities on total sugars (\%) in pointed gourd (Trichosanthes dioica Roxb.)

\begin{tabular}{|l|l|l|l|l|}
\hline & $\mathrm{S}_{1}$ & $\mathrm{~S}_{2}$ & $\mathrm{~S}_{3}$ & Mean \\
\hline $\mathrm{F}_{1}$ & 3.42 & 4.20 & 4.00 & $\mathbf{3 . 8 7}$ \\
\hline $\mathrm{F}_{2}$ & 4.19 & 5.67 & 4.84 & $\mathbf{4 . 9 0}$ \\
\hline $\mathrm{F}_{3}$ & 3.81 & 4.74 & 4.39 & $\mathbf{4 . 3 1}$ \\
\hline $\mathrm{F}_{4}$ & 2.81 & 3.02 & 3.00 & $\mathbf{2 . 9 5}$ \\
\hline Mean & $\mathbf{3 . 5 6}$ & $\mathbf{4 . 4 0}$ & $\mathbf{4 . 0 5}$ & \\
\hline
\end{tabular}

\begin{tabular}{|c|c|c|c|}
\hline & F & S & F X S \\
\hline SEm & 0.05 & 0.05 & 0.10 \\
\hline SEd \pm & 0.08 & 0.07 & 0.14 \\
\hline CD at 5\% & 0.17 & 0.14 & 0.29 \\
\hline
\end{tabular}

\section{Nutrient combinations}

$\mathrm{F}_{1}: 125: 50: 50 \mathrm{NPK} \mathrm{Kg} / \mathrm{ha}$

$\mathrm{F}_{2}: 150: 60: 60 \mathrm{NPK} \mathrm{Kg} / \mathrm{ha}$

$\mathrm{F}_{3}: 175: 70: 70 \mathrm{NPK} \mathrm{Kg} / \mathrm{ha}$

$\mathrm{F}_{4}:$ Control

\section{Plant densities}

$\mathrm{S}: 1 \mathrm{~m} \times 1 \mathrm{~m}$

$\mathrm{S}_{2}: 1.5 \mathrm{mx} 1.5 \mathrm{~m}$

$\mathrm{S}_{3}: 1.5 \mathrm{~m} \times 1 \mathrm{~m}$ 
Fig.1a Days taken for opening of first male flower

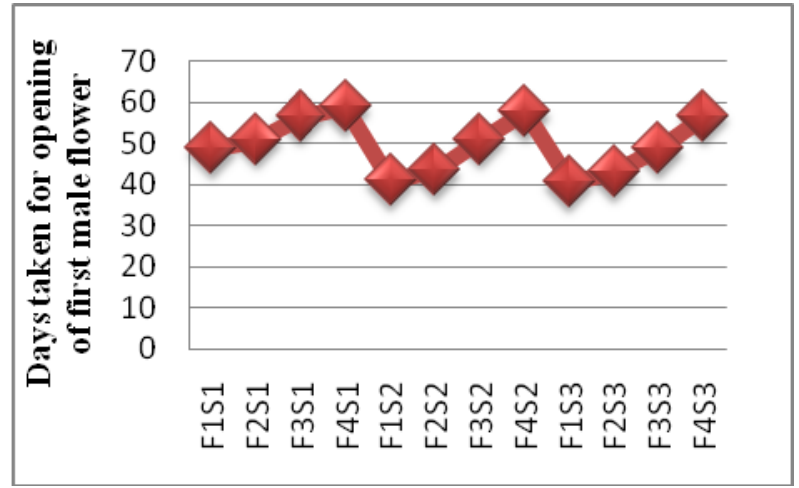

Fig.1b Days taken for opening of first female flower

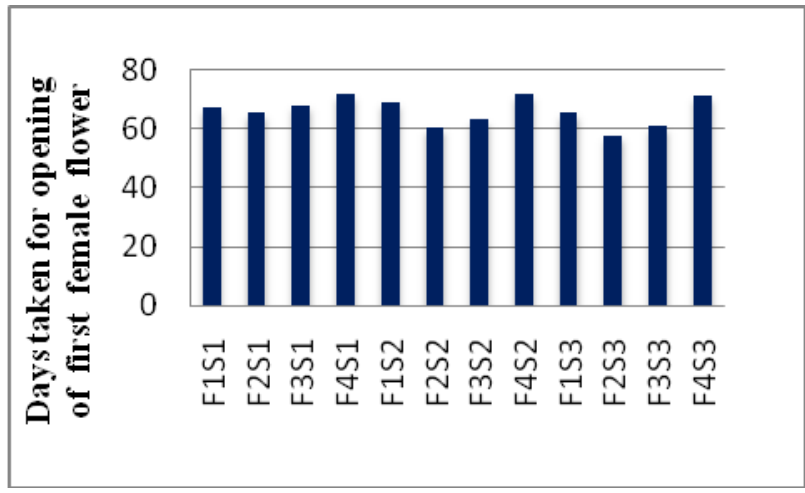

Fig.2 Effect of N, P, K levels and plant densities on number of fruits per vine in pointed gourd (Trichosanthes dioica Roxb.)

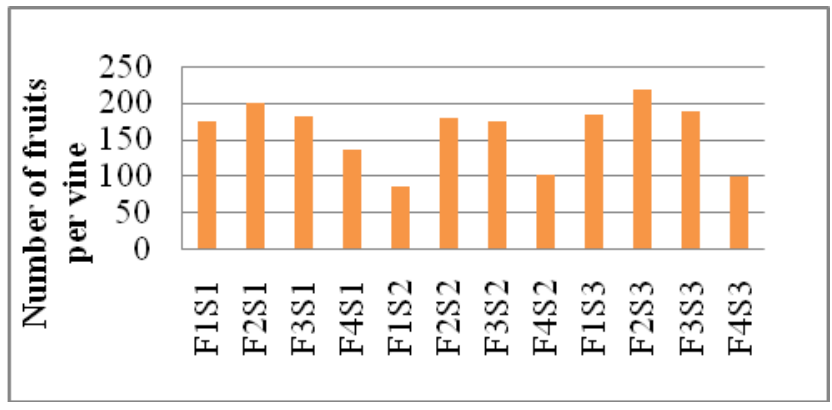

Fig.3 Effect of N, P, K levels and plant densities on weight of edible fruit (g), length of edible fruit $(\mathrm{cm})$ and fruit diamter $(\mathrm{cm})$ in pointed gourd (Trichosanthes dioica Roxb.)

Fig.3a Weight of edible fruit (g)

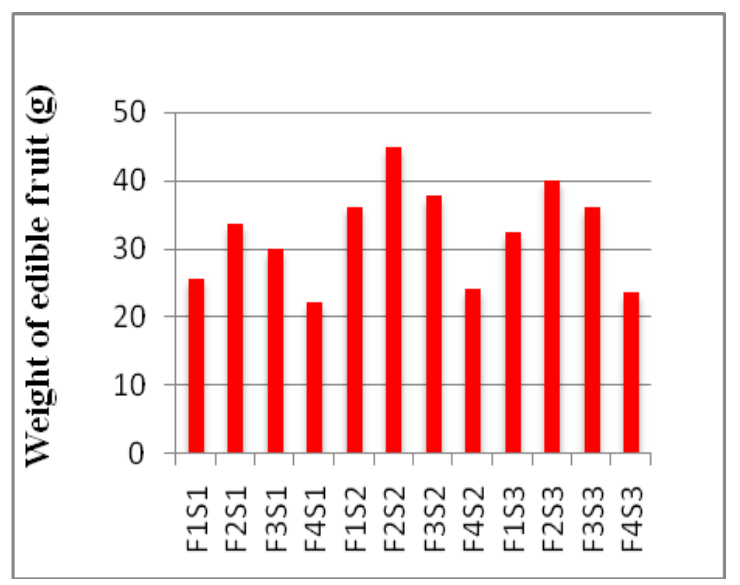

Fig.3a Length of edible fruit $(\mathrm{cm})$

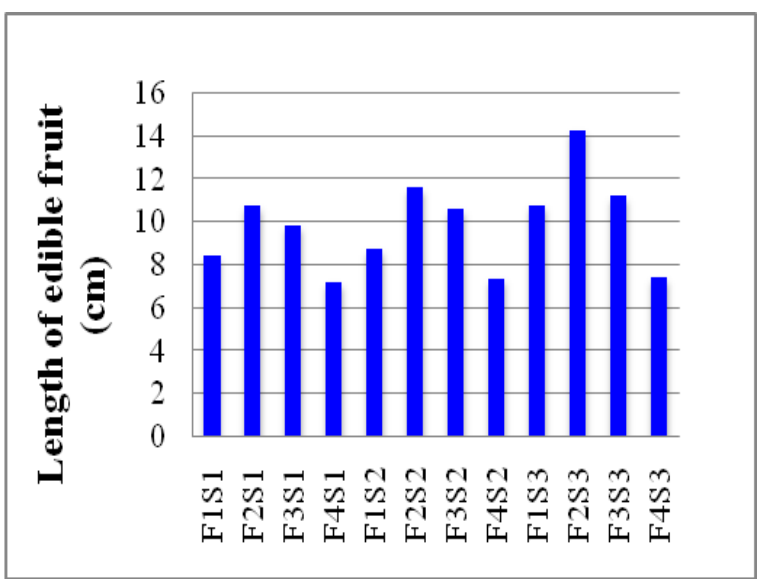


Fig.3c Fruit diameter (cm)

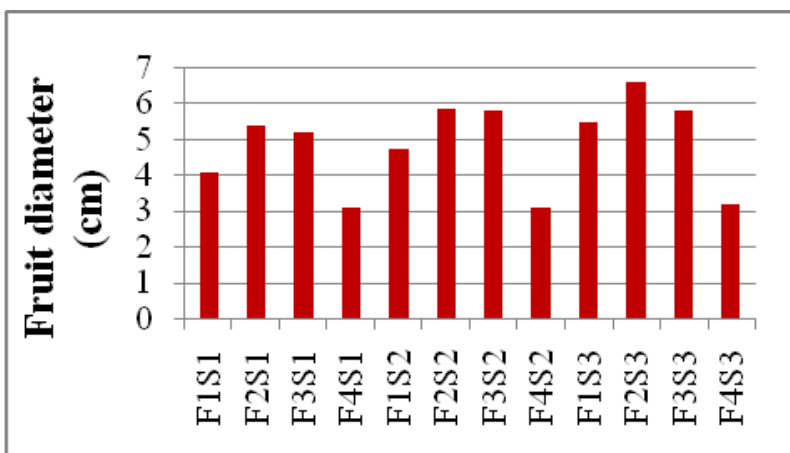

Fig.4 Effect of N, P, K levels and plant densities on total soluble solids ( ${ }^{\circ}$ Brix) in pointed gourd (Trichosanthes dioica Roxb.)

Fig.4a Ascorbic acid content (mg/100g)

Fig.4b Protein content $(\mathrm{g} / 100 \mathrm{~g})$

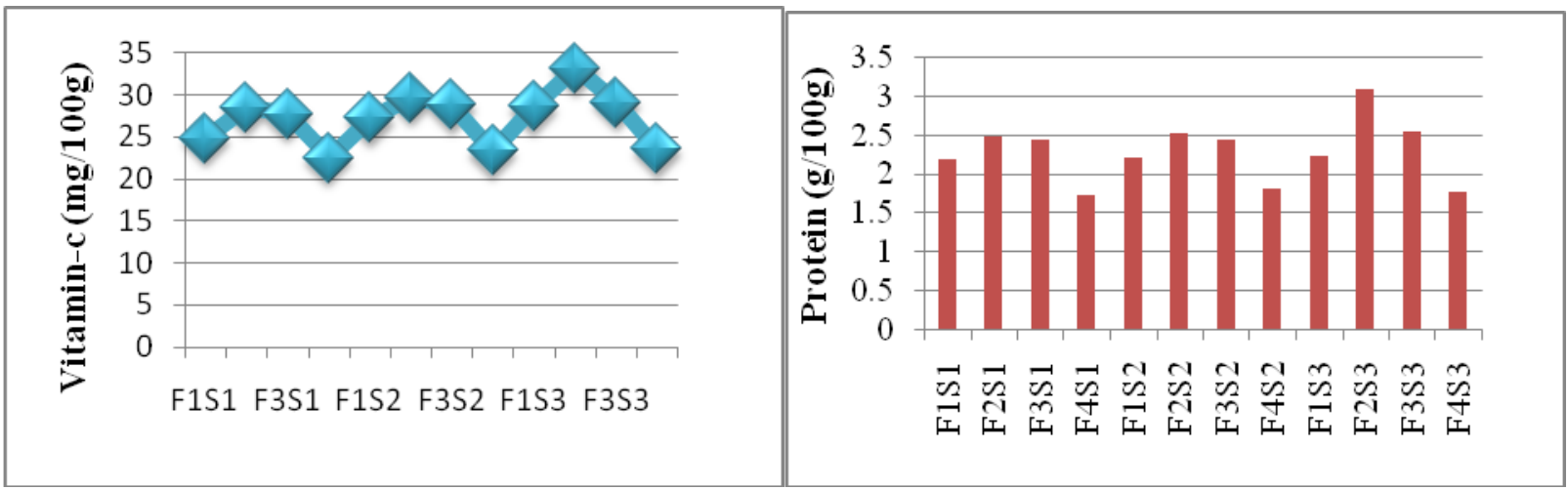

Fig.4c Total soluble solids $\left({ }^{\mathbf{0}}\right.$ Brix $)$

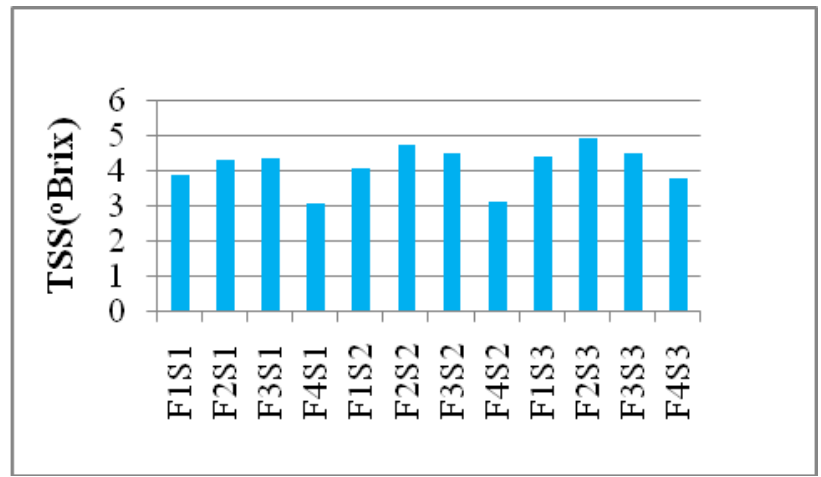




\section{Protein content $(\mathrm{g} / \mathbf{1 0 0 g})$}

Protein content was significantly influenced by the effect of N, P, K levels, plant densities and its interaction. Significantly maximum protein content $(3.08 \mathrm{~g}$ ) was noticed with the treatment combination of $\left(\mathrm{T}_{6}\right)-\mathrm{F}_{2} \mathrm{~S}_{3}$, followed by the treatment combination of $\left(\mathrm{T}_{9}\right)-\mathrm{F}_{3} \mathrm{~S}_{3}$ $(2.55 \mathrm{~g})$. Lowest protein content $(1.72 \mathrm{~g})$ was recorded with treatment $\left(\mathrm{T}_{10}\right)-\mathrm{F}_{4} \mathrm{~S}_{1}$ (Fig. $\left.4 \mathrm{~b}\right)$. These results were in conformity with the findings of Shivashankaramurthy et al., (2007) in gherkins.

\section{Reducing sugars (\%)}

The N, P, K fertilizer level, plant densities and their interaction effects significantly influenced the reducing sugars. Higher reducing sugars $(2.91 \%)$ were recorded with the treatment combination of $\left(\mathrm{T}_{5}\right)-\mathrm{F}_{2} \mathrm{~S}_{2}$ followed by the treatment combination of $\left(\mathrm{T}_{6}\right)-\mathrm{F}_{2} \mathrm{~S}_{3}(2.88 \%)$.

The lowest reducing sugars $(1.64 \%)$ were recorded with treatment $\left(\mathrm{T}_{10}\right)-\mathrm{F}_{4} \mathrm{~S}_{1}$ (Table 9). The highest reducing sugars with $\left(\mathrm{T}_{5}\right)-\mathrm{F}_{2} \mathrm{~S}_{2}$ may be due to better translocation and accumulation of nutrients. These results were in conformity with the findings of Dimri and Lal (1988) in tomato.

\section{Total sugars (\%)}

The interaction effect between N, P, K levels and plant densities on total sugars was found significant. The higher total sugars $(5.67 \%)$ were recorded with the treatment combination of $\left(\mathrm{T}_{5}\right)-\mathrm{F}_{2} \mathrm{~S}_{2}$ followed by the treatment combination of $\left(\mathrm{T}_{6}\right)-\mathrm{F}_{2} \mathrm{~S}_{3}(4.84 \%)$. The lowest total sugar $(2.81 \%)$ was recorded treatment $\left(\mathrm{T}_{10}\right)-\mathrm{F}_{4} \mathrm{~S}_{1}$ (Table 10). These results were in conformity with the findings of Dimri and Lal (1988) in tomato and Shivashankaramurthy et al., (2007) in gherkins.

\section{Total soluble solids $\left({ }^{0} \mathrm{Brix}\right)$}

Among different N, P, K fertilizer levels higher total soluble solids (4.67 ${ }^{\circ}$ Brix $)$ were recorded with $\mathrm{F}_{2}$ followed by $\mathrm{F}_{3}\left(4.47{ }^{\circ} \mathrm{Brix}\right)$ and the lower total soluble solids ( $\left.3.31{ }^{\circ} \mathrm{Brix}\right)$ were recorded with $\mathrm{F}_{4}$. These results were in conformity with the findings of Vishwakarma et al., (2007) in spine gourd, Anjanappa et al., (2012) in cucumber, Massri and Labban (2014) in water melon and Das et al (2015) in bottle gourd. These results were in conformity with the findings of Enas et al., (2002). The interaction on total soluble solids due to combined influence of fertilizers and plant densities was non significant (Fig. 4c).

In conclusion, the present work is done with the objectives of to study the effect of N, P, K levels, plant densities and the interaction between $\mathrm{N}, \mathrm{P}, \mathrm{K}$ levels, plant densities on growth, yield and quality of pointed gourd. Among the treatment combinations of $\mathrm{N}, \mathrm{P}, \mathrm{K}$ levels and plant densities, the treatment combination $\left(\mathrm{T}_{6}\right)-\mathrm{F}_{2} \mathrm{~S}_{3}: 150: 60: 60 \mathrm{NPK} \mathrm{kg} / \mathrm{ha}$ $+1.5 \mathrm{~m} \times 1 \mathrm{~m}$ recorded maximum values for growth, yield and quality parameters viz., number of nodes per vine, number of primary branches per vine, number of fruits per vine, fruit length, fruit diameter, yield per vine, yield per plot, total yield, number of seeds per fruit, fruit retention percentage, ascorbic acid content, protein content and total soluble solids and the minimum values were recorded for the parameters node at which first male flower appeared, node at which first female flower appeared, days taken to first harvest and days taken from fruit set to marketable maturity. However, the application of $\left(\mathrm{T}_{8}\right)-\mathrm{F}_{3}$ $\mathrm{S}_{2}: 175: 70: 70 \mathrm{NPK} \mathrm{Kg} \mathrm{ha}{ }^{-1}+1.5 \mathrm{~m} \times 1.5 \mathrm{~m}$ recorded maximum main vine length and internodal length whereas $\left(\mathrm{T}_{3}\right)-\mathrm{F}_{1} \mathrm{~S}_{3}$ : 125:50:50 NPK Kg ha ${ }^{-1}+1.5 \mathrm{~m} \times 1 \mathrm{~m}$ recorded minimum days taken for opening of first male flower and days taken for opening of first female flower. The application of $\left(\mathrm{T}_{5}\right)$ - 
$\mathrm{F}_{2} \mathrm{~S}_{2}: 150: 60: 60 \mathrm{NPK} \mathrm{kg} / \mathrm{ha}+1.5 \mathrm{~m} \mathrm{x} 1.5 \mathrm{~m}$ recorded maximum weight of edible fruit, 100 seed weight, reducing sugars and total sugars.

\section{References}

Aidy, F and El- Moustafa, S.A. 1978. Effect of plant density and fertilizer ratio on growth and yield of cucumber grown under plastic tunnels. Acta Horticulturae. 84: 73-78.

Aniekwe, N.L and Anike, N.T. 2015. Effects of Different Mulching Materials and Plant Densities on the Environment, Growth and Yield of Cucumber. Journal of Agriculture and Veterinary Science (IOSR-JAVS).8(11): 64-72.

Anjanappa, M., Venkatesha, J and Suresh Kumara, B. 2012. Growth, yield and quality attributes of cucumber (cv. Hassan local) as influenced by integrated nutrient management grown under protected condition. Vegetable Science 39(1): 47-50.

Arshad, I., Wajiha., Ali,H and Ahmed Khan, Zaheer. 2014. Effect of different levels of npk fertilizers on the growth and yield of greenhouse cucumber (Cucumis sativus) by using drip irrigation technology. International Journal of Agricultural Research (IJAR).1(8):650660.

Baloch, Q.B., Kaleri, I.A., Memon, N., Sharif, $\mathrm{N}$ and Chachar Q.I. 2013. Effect of various sowing patterns on growth and yield of Indian squash (Citrullus vulgaris). Journal of Agricultural Technology. 9(3):625-632.

Choudhari, S. M and More,T.A. 2002. Fertigation, fertilizer and spacing requirement of tropical gynoecious cucumber hybrids. Acta Horticulturae.233-240.

Das, M. K, Maity, T. K and Som, M. G. 2004. Growth and yield of pointed gourd (Trichosanthes dioica Roxb.) as influenced by nitrogen and phosphorous fertilization. Vegetable Science. 14(1):18-26.

Das, M. K., Maity, T. K and Som, M. G.1987. Growth and yield of pointed gourd (Trichosanthes dioica Roxb.) as influenced by nitrogen and phosphorus fertilization. Vegetable Science. 14(1): 18-26.

Das, R., Mandal, A. R., Priya, A., Das, S. P and Kabiraj, J. 2015. Evaluation of integrated nutrient management on the performance of bottle gourd [Lagenaria siceraria (Molina) Standl.]. Journal of Applied and Natural Science. 7 (1): 18 25.

Dash, S. K and Tripathy, L. 2001. Studies on different plant density models on growth and flowering of pointed gourd (Trichosanthes dioica Roxb.) South Indian Horticulture. 49: 55-57.

Dimri, D. C and Lal, G.1988. Effect of nitrogen fertilization, spacing and method of planting on yield parameters and quality of tomato cultivar Pant Bahar. Vegetable Science. 15 (2): 105112.

Ekmw, L.G and Nwokwu, G.N. 2012. Effects of plant spacing and planting date on the growth and yield of Okra (Abelmoscus esculentus L) in Abakaliki. Int'l journal of agric.and rural dev., 15(2): 1041-1048.

Enas, A., Qudeimat, Azmi M., Abu-Rayyan and Ahmad, M. Abu-Awwad. 2002. The effects of plant spacing and irrigation levels on muskmelon (Cucumis melo L.) crop water requirement, fruit quality and yield were studied at the University of Jordan Research Station in the Jordan Valley.

Hazra, P., Chattopadhyay, A., Karmakar and Dutta, S. 2011. Modern technology in vegetable production. New India publishing Agency. Pitam pura, New Delhi.pp.380-384. 
Jackson, M.L. 1973. Soil chemical analysis. Prentice-Hall of India Private Limited, New Delhi.

Jan, M., Iqbal M., Ghafoor, N.D., Waseem, A., Jillani, K., M.S and Khan, D.I. 2000. Effect of NPK fertilizers and spacing on the yield of bottle gourd (Lagenaria siceratia M). Pakistan journal of Biological Sciences 3(3): 448-449.

Kanwar, D.P.S., Diksit, S.N., Sharma,G.L., Patel, K.L., Rajesh Agrawal and Sarnaik, D.A. 2013. Studies on effect of fertigation on growth and yield attributing characters of sweet pepper (Capsicum annum L.) under black polythene mulch. J.soils and crops. 23(1):73-77.

Karataev, E. S and Sal'nikova, M. B.1982. Effect of planting density on the growth and development of parthenocarpic cucumbers. Intensifik. Vozdelyvaniya Ovoshch. Plod. i Yagod. Kul'tur pp. 2729.

kumar, V., Vinay kumar Singh and Teena rani. 2012. Effect of integrated nutrient management on Economics in Bottlegourd (Lagenaria siceraria L.). Environment \& ecology. 30(4a):14101412.

Laghari, M.H., Mugheri, A.A., Sheikh, S.A and Wahocho, N.A. 2014. Response of nitrogen levels on the growth and yield of bottle gourd varieties. International Journal of Agronomy and Agricultural Research (IJAAR) 5(6):86-92.

Massri, M and Labban, L. (2014). Comparison of Different Types of Fertilizers on Growth, Yield and Quality Properties of Watermelon (Citrllus lanatus). Agricultural Sciences. 5: 475-482.

Maynard, G., Hale and David, M., Orcutt. 1987. In the physiology of plants under stress. A Wiley Inter Science Publications, New York pp 71-72 and
145-166.

Mia, B., M.A., Serajul Islam, Md., Yunus Miah, Md., Das, M.R and Khan, H.I. 2014. Flower synchrony, growth and yield enhancement of small type bitter gourd (Momordica charantia L.) through plant growth regulators and NPK fertilization. Pakistan journal of biological sciences. 17(3):408-413.

Misra, R.S., Kumar, R., siohi, r.k and Misra, S.P. 1994. Nutritional studies in parwal (Trichosanthes dioica Roxb). Recent Hort. 1(1): 58-60.

Mondal,B., Das, R., Saha, G and Khatua, D.C. 2014. Downy mildew of pointed gourd and its management. Scholars Academic Journal of Biosciences (SAJB). 2(6): 389-392.

Muhr, G.R. 1965. Soil testing in India, USAID, New Delhi. Pp. 120.

Oga, I.O and Umekwe, P. N. 2016. Effects of pruning and plant spacing on the growth and yield of watermelon (Citrullus lanatus L.) in Unwana-Afikpo. International Journal of Science and Research. 5 (4):110-115.

Oloyede, F.M., Agbaje G.O and Obisesan, I.O. 2013. Effect of NPK fertilizer on fruit yield and yield components of pumpkin (Cucurbita pepo Linn.). Ajfand. 13(3).

Olsen, S.R., Cole, C.V., Watanabe, F.S and Dean, L.A. 1954. Estimation of available phosphorus in soils by extraction with $\mathrm{NaHCO}_{3}$. Cir. U.S. Deptt. Agric. 939.

Panday, A.K and Ram, D. 2000. Effect of IBA, NAA and node number in regeneration of pointed gourd (Trichosanthes dioica Roxb.) by stem cuttings.Prog.Hort., 32: 172-175.

Patro,T.S.K.K.K and Mallareddy, K. 2009. Effect of spacing and fertilizers on yield attributing characters in kakrol (Momordica dioica Roxb.) The Andhra Agric. J., 56(4):480-492. 
Piper, C.S.1996. Soil and plant analysis (Ed) Indian Edition. Hans Publ. Bombay.

Prasad, P.H., Mandal, A.R., Sarkar, A., Thapa, U and Maity, T.K. (2009). Effect of bio fertilizers and nitrogen on growth and yield attributes of bitter gourd (Momordica charantia L.). International conference of horticulture. Pp.738-740.

Rani, R., Nirala, S.K and Suresh, R. 2012.Effect of fertigation and mulch on yield of pointed gourd in calcareous soil of North Bihar. Environment and Ecology. 30(3A):641-645.

Singh, K.P., Krishna Mohan,T and Haque, M. 2007.Studies on planting time, method and plant density on yield and yield attributing characters on pointed gourd (Trichosanthes dioica Roxb.) in Gangetic diara of Bihar. Asian journal of horticulture. 2(1): 47-49.

Singh, P.K., Singh, K.K., Yadav, C.B.S., Pradeep, Singh, K and Joshi, G. 2012. Effect of intra-row spacing and pruning on yield, water use and economics of tomato production under naturally ventilated bamboo polyhouse. Pantnagar journal of research.10 (1):91-94.

Subbaiah, B.Y and Asija, G.L. 1956. A rapid procedure for estimation of available nitrogen in soils. Current Science. 25: 259-260.

Sureshkumar, R and Johnson, Naorem. 2015. Effect of phosphorus and potassium on growth and yield characters of bitter gourd (Momordica charantia 1.) Ecotype mithipagal. The Asian journal of horticulture. 10(2): 207-211.
UmaMaheswarappa, P., Krishnappa, K. S., Pitchai Muthu, M., Nachegowda, V and Venkatesha Murthy, P. 2002. Flowering, fruit set, fruit size and yield of bottle gourd in relation to varying levels of $\mathrm{N}, \mathrm{P}$ and $\mathrm{K}$ in southern dry region of Karnataka. South Indian Horticulture. 50(4-6): 404-413.

Umekwe, P. N., Okpani, F. M and Okocha, I. O. 2015. Effects of Different Rates of NPK 15:15:15 and pruning methods on the growth and yield of cucumber (Cucumis sativus L.) in UnwanaAfikpo. International Journal of Science and Research (IJSR).4(10):3639.

Vishwakarma, S. K., Gautam, D.S., Yadav, N.S and Gautam, S.S. 2007. Effect of different levels of nitrogen and phosphorus on growth, yield and quality of spine gourd (Momordica dioica Roxb.) Technofame - A Journal of Multidisciplinary Advance Research, Pp: 120-123.

Wazed, M. A., Rahman, M.J., Chawdhery, M. R.A and Islam, M. N. 2013. Improvements of fruit set and yield by hormone application and fertilizer management practices in snake gourd. International Journal of Sustainable Agricultural Technology.9 (8):15-19.

Yadav, J. P., K and Jaiswal, R. C. 1989. Influence of various spacings and methods of training on growth and yield of pointed gourd (Trichosanthes dioica Roxb.). Vegetable Science. 16(2):113118.

\section{How to cite this article:}

Siva, M., T.S.K.K. Kiran Patro, D. Dayeswari, D.V. Swami, N. Emmanuel and Laksminarayana Reddy, M. 2018. Studies on the Effect of N, P, K Levels and Plant Densities on Growth, Yield and Quality of Pointed Gourd (Trichosanthes dioica Roxb.). Int.J.Curr.Microbiol.App.Sci. 7(12): 1315-1331. doi: https://doi.org/10.20546/ijcmas.2018.712.161 